\title{
A global modulatory role for the Yersinia enterocolitica $\mathrm{H}-\mathrm{NS}$ protein
}

\begin{abstract}
Correspondence
Antonio Juárez

ajuarez@ub.edu
\end{abstract}

Received 5 December 2007

Revised 12 February 2008

Accepted 13 February 2008

\author{
Rosa C. Baños, ${ }^{1}$ José I. Pons, ${ }^{2}$ Cristina Madrid ${ }^{2}$ and Antonio Juárez ${ }^{1,2}$ \\ ${ }^{1}$ Institut de Bioenginyeria de Catalunya, Parc Científic de Barcelona, Edifici Hèlix. c/ Josep Samitier \\ 1-5, 08028 Barcelona, Spain \\ ${ }^{2}$ Departament de Microbiologia, Facultat de Biologia, Universitat de Barcelona, Avda Diagonal \\ 645, 08028 Barcelona, Spain
}

\section{INTRODUCTION}

In enteric bacteria, the nucleoid-associated H-NS protein plays a role both as an architectural protein and as a global modulator of gene expression (Dorman, 2004). In many instances, gene regulation processes that require $\mathrm{H}-\mathrm{NS}$ respond to environmental changes such as osmolarity, $\mathrm{pH}$ or temperature variations (Tupper et al., 1994). It is therefore not surprising that the H-NS protein has been found to play an important role in the regulation of the expression of virulence determinants. H-NS-modulated operons usually contain two target sequences, which have often been characterized as being AT-rich curved DNA stretches (Rimsky, 2004). A current hypothesis that is supported by experimental evidence considers that H-NS binding to its target sequences is followed by an oligomerization process. A DNA loop should then be generated, bringing the two target sites into closer contact. The resulting nucleoprotein complex influences expression of the genes affected (Dorman \& Deighan, 2003; Falconi et al., 1998; Rimsky, 2004). When considering such a model, changes in physico-chemical properties of the DNA region to which H-NS binds may be essential to facilitate DNA bridging. Thus, temperature-mediated changes in DNA supercoiling and hence in DNA flexibility may affect the ability of H-NS to modulate expression of certain genes or operons (Falconi et al., 1998; Madrid et al., 2002). In addition to indirect effects on DNA, temperature and/or other factors may also influence the ability of H-NS itself to dimerize/oligomerize and to facilitate the interaction with DNA (Ono et al., 2005; Stella et al., 2006).
The modulatory properties of H-NS can also be influenced by heteromeric interactions (Dorman, 2004), such as those with members of the Hha-YmoA family of proteins (Madrid et al., 2007a, b; Nieto et al., 2000, 2002). These proteins show structural mimicry of the H-NS oligomerization domain and form complexes with $\mathrm{H}$-NS that modulate gene expression (Ellison \& Miller, 2006; Madrid et al., 2002; Nieto et al., 2002). The chromosomes of many members of the Enterobacteriaceae encode paralogues of both H-NS [the StpA protein (Sondén \& Uhlin, 1996)] and Hha [the YdgT protein (Paytubi et al., 2004)]. Remarkably, members of the genus Yersinia contain single copies of the $h n s$ and hha genes.

Virulence gene expression in Yersinia enterocolitica has been extensively studied by different laboratories. Thermoregulation of virulence gene expression in this micro-organism is a well-documented process (Rohde et al., 1994; Straley \& Perry, 1995), but the mechanism by which temperature regulates virulence expression is not completely understood. YmoA is a regulatory protein found to participate in this process (Cornelis et al., 1991). $y m o A$ mutants of $Y$. enterocolitica show a pleiotropic phenotype very reminiscent of that of classical hns mutants of Escherichia coli and Shigella, e.g. alterations in the supercoiling state of the DNA and in the expression of temperature-regulated genes (Mikulskis \& Cornelis, 1994). YmoA shows extensive similarity to the E. coli Hha protein and other proteins of the same family (Madrid et al., 2007a, b). We described that Hha and H-NS interact to modulate gene expression (Madrid et al., 2002; Nieto et al., 2000). 
This interaction is also apparent for other members of both families of proteins, i.e. YmoA and $\mathrm{H}-\mathrm{NS}$ or YdgT and $\mathrm{H}$ NS (Ellison \& Miller, 2006; Nieto et al., 2000; Paytubi et al., 2004). Whereas hns mutants have been isolated in different members of the Enterobacteriaceae such as E. coli, Salmonella and Shigella, it has not been hitherto possible to isolate hns mutants in the genus Yersinia. The few examples reported of Yersinia genes that are modulated by $\mathrm{H}-\mathrm{NS}$ used the surrogate E. coli hns background (Ellison \& Miller, 2006; Heroven et al., 2004; Pérez-Gutiérrez et al., 2007). In this study we altered H-NS function in $Y$. enterocolitica by expressing the $\mathrm{H}-\mathrm{NST}_{\mathrm{EPEC}}$ protein, reported to antagonize H-NS in E. coli (Williamson \& Free, 2005). Y. enterocolitica cells expressing H-NST $\mathrm{EPEC}_{\mathrm{EP}}$ showed an altered growth rate and significant differences in the protein expression pattern. We further used this strategy to show that $\mathrm{H}-\mathrm{NS}$ modulates expression of the ymoA gene.

\section{METHODS}

Bacterial strains, plasmids and culture conditions. Bacterial strains and plasmids used in this study are listed in Table 1. The strains were grown in Luria-Bertani (LB) medium ( $10 \mathrm{~g} \mathrm{NaCl}, 10 \mathrm{~g}$ tryptone and $5 \mathrm{~g}$ yeast extract per litre). Antibiotics, when required, were used at the following concentrations: ampicillin (Ap), $50 \mu \mathrm{g} \mathrm{ml}^{-1}$; kanamycin $(\mathrm{Km}), 50 \mu \mathrm{g} \mathrm{ml}^{-1}$; chloramphenicol $(\mathrm{Cm}), 12.5 \mu \mathrm{g} \mathrm{ml}^{-1}$.

To construct plasmid pJOB101-Km a mini-Tn5-based mutagenesis was used (De Lorenzo et al., 1990). First, pUTmini-Tn5Km1 was mobilized from donor strain E. coli S17-1 $\lambda$ pir to recipient strain $E$. coli $5 \mathrm{~K}$ (pJOB101) by a filter mating technique (Herrero et al., 1990). Plasmids from kanamycin-resistant $\left(\mathrm{Km}^{\mathrm{r}}\right)$ transconjugants were isolated and transformed into E. coli $5 \mathrm{~K} . \mathrm{Km}^{\mathrm{r}}$ transformants were selected and replica printed on Ap plates to test for the loss of the Ap ${ }^{\mathrm{r}}$ marker. Therefore it could be verified that no essential function of plasmid pJOB101 was affected by mini-Tn 5 insertion. To mobilize plasmid pJOB101-Km from E. coli to Yersinia, E. coli S17.1 was used as donor strain.

To construct plasmid pETHNSYhis, the hns gene of $Y$. enterocolitica strain W22703 was PCR amplified using oligonucleotides HNSYNDE (5'-GGGAATTCCATATGAGCGAAGCGTTAAAGATTC-3'), which adds an NdeI site to the sequence encoding the $\mathrm{N}$-terminus of $\mathrm{H}$ NS protein, and HNSYHISBAM (5'-CGGGATCCTATTAATGGTGATGGTGATGGTGCAGCAGGAAATCATCCAGTG-3'), which adds a $\mathrm{His}_{6}$-tag-encoding sequence plus a $\mathrm{BamHI}$ site to the sequence encoding the C-terminus of H-NS protein. The NdeI-BamHI PCR fragment was cloned into a modified plasmid pET15b, which contains the PstI-XbaI fragment with the cloning/expression region of plasmid pET3b.

To construct plasmid pETHNSTEPEC, the $h n s T_{\mathrm{EPEC}}$ gene from plasmid pHSGHNSTE was amplified by PCR using oligonucleotides TENDE (5'-AGTCTATCCAAGGAGCAAACATATGATTGATG-3'), which adds an NdeI site to the sequence encoding the N-terminus

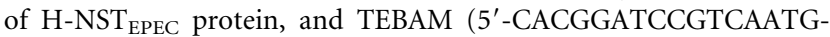
AGATCTTCTGGCG-3'), which adds a BamHI site after the $h n s T_{\mathrm{EPEC}}$ gene. The NdeI-BamHI PCR fragment was cloned into the modified plasmid pET15b as described above.

Genetic and molecular procedures. Isolation of plasmids and transformation were carried out by standard methods. Electroporation of Y. enterocolitica cells was performed as previously described (Conchas \& Carniel, 1990).

Overexpression of proteins by the T7 RNA polymerase system and purification of His-tagged proteins. E. coli strain BL21(DE3) $\Delta h n s$ was used as a host induction of expression of proteins. Plasmids containing the desired cloned genes (pET plasmids) were introduced by transformation into the strain used. One-litre cultures were grown to an $\mathrm{OD}_{600}$ of 0.3 , and at this point IPTG was added to $0.5 \mathrm{mM}$. Incubation was continued for $2 \mathrm{~h}$. Cells were pelleted by centrifugation and resuspended in $20 \mathrm{ml}$ buffer A (20 mM HEPES pH 7.9,

Table 1. Strains and plasmids used in this study

\begin{tabular}{|c|c|c|}
\hline Strain or plasmid & Description & Source or reference \\
\hline \multicolumn{3}{|l|}{ Strains } \\
\hline Y. enterocolitica W22703 & $\mathrm{Nal}^{\mathrm{r}}$, serotype $\mathrm{O}: 9, \mathrm{R}^{-} \mathrm{M}^{+}$ & Cornelis \& Colson (1975) \\
\hline Y. enterocolitica W22711 & W22703 ymoA::Tn5-Tc1 & Cornelis et al. (1991) \\
\hline E. coli $5 \mathrm{~K}$ & $\mathrm{~F}^{-}$hsdR hsdM thr thi rpsL leu lacZ & Juárez et al. (1984) \\
\hline E. coli S17-1 $\lambda$ pir & $\mathrm{Tp}^{\mathrm{r}} \mathrm{Sm}^{\mathrm{r}}$, recA thi pro hsd $\mathrm{R}^{-} \mathrm{M}^{+} \mathrm{RP} 4: 2-\mathrm{Tc}: \mathrm{Mu}: \mathrm{Km} \mathrm{Tn} 7$ pir & Miller \& Mekalanos (1988) \\
\hline E. coli $\mathrm{S} 17-1$ & recA thi pro hsdR Rp4-2 (Tn $1::$ ISR1 tet:: $\mathrm{Mu} \mathrm{Km::Tn7)}$ & Simon et al. (1983) \\
\hline E. coli BL21(DE3) $\Delta h n s$ & $\Delta h n s:: \mathrm{Km}$ & Zhang et al. (1996) \\
\hline \multicolumn{3}{|l|}{ Plasmids } \\
\hline pJOB101 & ori $_{\mathrm{RSF} 1010} h n s^{+} \mathrm{Ap}^{\mathrm{r}}$ & Johansson et al. (2001) \\
\hline pUTmini-Tn $5 K m 1$ & ori $_{\mathrm{R} 6 \mathrm{~K}} \operatorname{mini}-\mathrm{Tn} 5 \mathrm{Km} 1$ & De Lorenzo et al. (1990) \\
\hline pJOB101-Km & pJOB101, Ap :: mini-Tn5Km1 & This work \\
\hline pHSGHNSTE & $h n s T_{\mathrm{EPEC}}$ in $\mathrm{pHSG} 576$ & Williamson \& Free (2005) \\
\hline pHSG576 & ori $_{p S C 101}$ lacZ $\alpha \mathrm{Cm}^{\mathrm{r}}$ & NRBP (NIG, Japan): E. coli \\
\hline pHly152 & hlyR hlyC hlyA hlyB hlyD & Noegel et al. (1981) \\
\hline pET3b & $\mathrm{Ap}^{\mathrm{r}}, \mathrm{T} 7$ promoter & Studier et al. (1990) \\
\hline pET15b & ori $_{\mathrm{PMB} 1} \mathrm{Ap}^{\mathrm{r}}, \mathrm{T} 7$ promoter & Novagen (Madison) \\
\hline pETHNSHis & pET3b hns E. coli His-tag $\mathrm{Ap}^{\mathrm{r}}$ & Nieto et al. (2002) \\
\hline pETHNSYHis & $\mathrm{pET}+$ hns Y. enterocolitica His-tag $\mathrm{Ap}^{\mathrm{r}}$ & This work \\
\hline pETHNSTEPEC & $\mathrm{pET}+h n s \mathrm{~T}_{\mathrm{EPEC}} \mathrm{Ap}^{\mathrm{r}}$ & This work \\
\hline
\end{tabular}




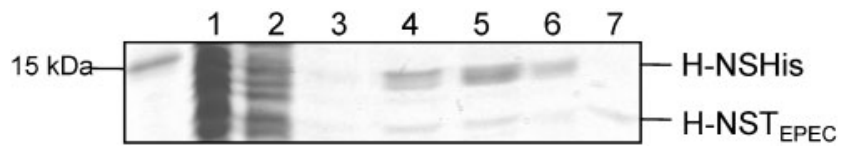

Fig. 1. Interaction between $\mathrm{H}-\mathrm{NSH}$ is and $\mathrm{H}-\mathrm{NST}_{\mathrm{EPEC}}$. Coomassie-blue-stained SDS-PAGE gel loaded with fractions eluted from $\mathrm{Ni}^{2+}$-NTA agarose matrix after binding to two different cellular extracts from IPTG-induced cultures of $E$. coli BL21(DE3) $\Delta h n s$ transformed with plamids pETHNSYHis and pETHNSTEPEC. Lanes 1, 2 and 3 correspond to buffer $A$ washes of the agarose matrix. Lanes 4, 5 and 6 correspond to elution of the bound proteins with buffer A plus $200 \mathrm{mM}$ imidazole. Lane 7: overproduced $\mathrm{H}-\mathrm{NST}_{\text {EPEC }}$ cell extract.

$100 \mathrm{mM} \mathrm{KCl}, 5 \mathrm{mM} \mathrm{MgCl}$, $20 \mathrm{mM}$ imidazole). The cells were lysed by three passages through a French press at 1000 p.s.i. The lysed extract was centrifuged at $12000 \mathrm{~g}$ for $30 \mathrm{~min}$ at $4{ }^{\circ} \mathrm{C}$. His-tagged $Y$. enterocolitica $\mathrm{H}-\mathrm{NS}$ protein was purified by immobilized metal-affinity chromatography by using $\mathrm{Ni}^{2+}$-NTA technology (Hoffmann \& Roeder, 1991), as described previously (Nieto et al., 2000).

Preparation of cell extracts and 2D electrophoretic analysis of proteins. For 2D gel electrophoresis, cells were grown in LB medium at $30{ }^{\circ} \mathrm{C}$. Samples $(250 \mathrm{ml})$ were collected at the exponential growth phase $\left(\mathrm{OD}_{600} 0.6\right)$ and cells harvested by centrifugation $(10 \mathrm{~min}$, $\left.5000 \mathrm{~g}, 4{ }^{\circ} \mathrm{C}\right)$. The pellets were washed four times by centrifugation for $10 \mathrm{~min}$ at $2000 \mathrm{~g}, 4{ }^{\circ} \mathrm{C}$ in $10 \mathrm{ml}$ low-salt washing sample buffer (3 mM KCl, $1.5 \mathrm{mM} \mathrm{KH}_{2} \mathrm{PO}_{4}, 68 \mathrm{mM} \mathrm{NaCl}, 9 \mathrm{mM} \mathrm{NaH}{ }_{2} \mathrm{PO}_{4}$ ). Cells were then resuspended in $300 \mu \mathrm{l}$ of a buffer containing $10 \mathrm{mM}$ Tris/ $\mathrm{HCl} \mathrm{pH} \mathrm{8.0,} 1.5 \mathrm{mM} \mathrm{MgCl}_{2}, 10 \mathrm{mM} \mathrm{KCl}, 0.5 \mathrm{mM}$ DTT, $0.5 \mathrm{mM}$ PMSF, $0.1 \%$ Triton $\mathrm{X}-100$, and stored at $-20{ }^{\circ} \mathrm{C}$. Crude extracts were prepared by mixing $15 \mu \mathrm{l}$ of the corresponding cell suspension with $300 \mu \mathrm{l}$ of a solution containing urea $(7 \mathrm{M})$, thiourea $(2 \mathrm{M})$, CHAPS $(4 \% \mathrm{w} / \mathrm{v})$, DTT $(65 \mathrm{mM})$ and a trace of bromophenol blue. After centrifugation at $10000 \mathrm{~g}$ for $20 \mathrm{~min}, 4{ }^{\circ} \mathrm{C}$, the supernatant was collected and samples were stored at $-80{ }^{\circ} \mathrm{C}$.

Immobiline DryStrips ( $24 \mathrm{~cm}, \mathrm{pH}$ 3-11 NL, Amersham Biosciences) were rehydrated at $50 \mathrm{~V}$ for $10 \mathrm{~h}$ with $150 \mu$ g protein from crude extract supplemented with $0.5 \%(\mathrm{v} / \mathrm{v})$ of the appropriate IPG buffer (Amersham Biosciences). Isoelectric focusing was carried out according to the manufacturer's protocol (IPGphor, Amersham Biosciences). Prior to second-dimension electrophoresis, strips were equilibrated for $15 \mathrm{~min}$ in equilibration buffer [30\% (v/v) glycerol, $2 \%(\mathrm{w} / \mathrm{v})$ SDS, $6 \mathrm{M}$ urea, $50 \mathrm{mM}$ Tris/ $\mathrm{HCl}$, trace of bromophenol blue, $\mathrm{pH} 8.8$ ] containing $65 \mathrm{mM}$ DTT. This step was repeated using equilibration buffer supplemented with $100 \mathrm{mM}$ iodoacetamide. The strips were then embedded in $0.5 \%$ agarose and the proteins resolved by electrophoresis through $12.5 \%$ SDS-PAGE (Ettan DALT six, Amersham Biosciences) at $2.5 \mathrm{~W}$ per gel for $30 \mathrm{~min}$, followed by $100 \mathrm{~W}$ for 3-4 h. For protein identification, gels were silver-stained and digitized by transmission scanning (ImageScanner, Amersham Biosciences). Spots excised from the gel were stored at $4{ }^{\circ} \mathrm{C}$ until identification by MALDI-TOF MS or ESI-MS-MS.

In-gel digestion and acquisition of mass spectra. Proteins were in-gel digested with trypsin (Sequencing grade modified, Promega) in a Genomic Solutions automatic Investigator ProGest robot. Spots excised from the 2D gels were analysed by either MALDI-TOF/TOF MS (4700 Proteomics Analyser, Applied Biosystems) or ESI-MS-MS (Q-TOF Global, Micromass-Waters). Data were submitted for database searching in the MASCOT server.

Western blot analysis. Cells were grown in LB medium at $30{ }^{\circ} \mathrm{C}$. Aliquots were collected at the exponential growth phase $\left(\mathrm{OD}_{600} 0.6\right)$. After centrifugation, cells were resuspended in $10 \mathrm{mM}$ potassium phosphate buffer pH 7.0, $1 \mathrm{mM}$ EDTA, $5 \mathrm{mM} \beta$-mercaptoethanol, $0.1 \mathrm{mM}$ PMSF, 0.5 M NaCl (Straley \& Perry, 1995). Cell lysates were obtained by sonication and the protein concentration was evaluated (Bradford Bio-Rad). Proteins were electrophoretically separated and transferred to nitrocellulose membranes. To obtain H-NS-specific antibodies, $\mathrm{H}-\mathrm{NS}-\mathrm{His}_{6}$ protein was overproduced from plasmid pETHNSHis as described previously (Nieto et al., 2002) and eluted from Tricine-SDS-PAGE gels in $0.2 \mathrm{M}$ Tris/ $\mathrm{HCl} \mathrm{pH} 8.9$ prior to injection into rabbits by standard procedures. Testing the extracted serum allowed us to confirm that it was able to recognize H-NS protein and not give any cross-reaction to $\mathrm{H}-\mathrm{NST}_{\mathrm{EPEC}}$ (data not shown). To immunodetect YmoA, we used polyclonal antibodies raised against E. coli tha protein, which also recognize YmoA (Balsalobre et al., 1996).

Total RNA isolation. To be used in RT-PCR assays, total RNA from different strains was isolated by using the SV Total RNA Isolation System (Promega). Total RNA was quantified using a NanoDrop spectrophotometer (NanoDrop Technologies). When necessary, DNA was eliminated with Turbo DNase (Ambion).
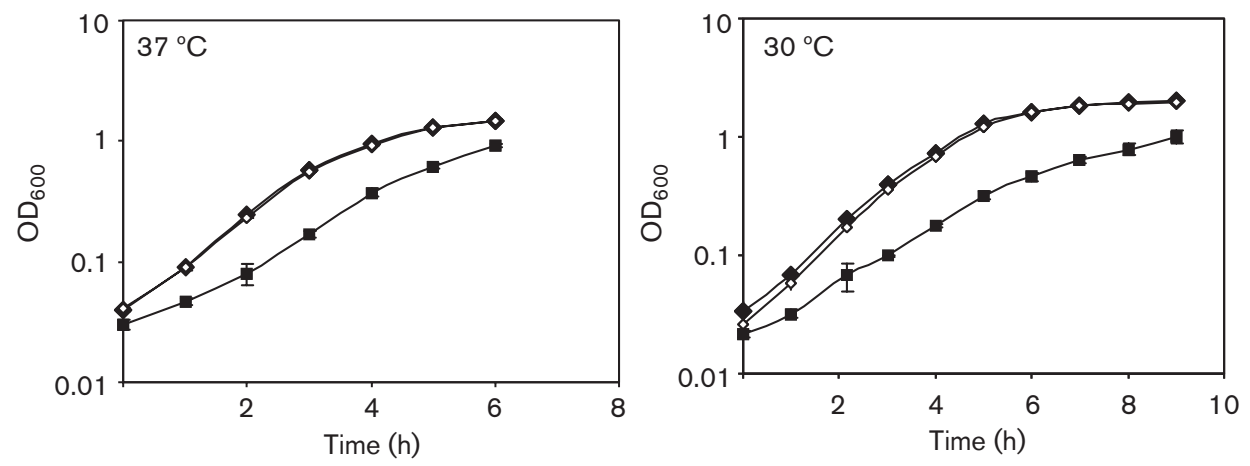

Fig. 2. Growth of strains W22703 ( $)$, W22703(pHSG576) $(\diamond)$ and W22703(pHSGHNSTE) ( $\mathbf{\square})$ in LB medium aerobically at $37{ }^{\circ} \mathrm{C}$ and $30{ }^{\circ} \mathrm{C}$. The mean $\pm \mathrm{SD}$ of three independent cultures for each strain is presented (error bars not shown where smaller than symbols). 

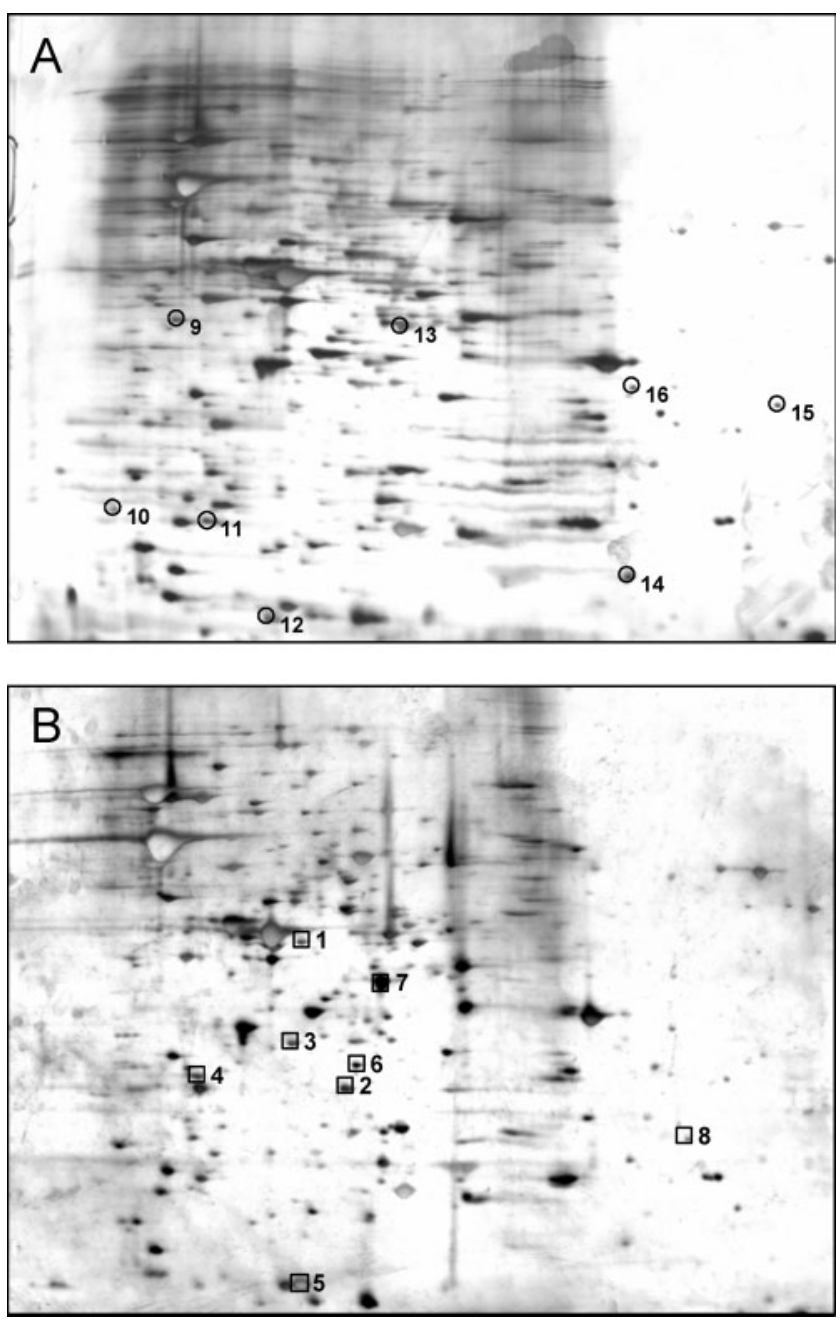

Fig. 3. 2D-PAGE analysis of cell extracts from strains W22703 (A) and W22703(pHSGHNSTE) (B). Spots 1 to 8 (in squares) correspond to proteins that, when compared to the plasmid-free strain, show induced expression in strain W22703(pHSGHNSTE). Spots 9 to 16 (circled) correspond to proteins showing increased expression in strain W22703. See Table 2 for identities of spots $1-16$.

RT-PCR. To determine the specific mRNA levels of different genes, we used Ready-to-Go RT-PCR beads (Amersham Biosciences). The primer pairs used were HNSTUP/HNSTDOWN (5'-CGCAACCACTGACCTCAAA-3')/(5'-AGATCTTCTGGCGAAACCC-3'), (GLNH5/GLNH3 (5' -ATCACTTACACCGACGAACG-3'/5' -AAGTGCCGTCTTCTTTCAGG-3'), PROU5/PROU3 (5'-CGATACGGTAACCCACAATC-3' $/ 5^{\prime}$-GGTTCGAGTAGTCAGTTGGA-3'), YEN16S-5'/ YEN16S-3' (5' -TGAGTAATGTCTGGGAAACT-3'/5' -TTCTTCTGCGAGTAACGTC-3') and YmoA-RT/YmoA-PCR (5'-ACATGTTGCCATACAGTAGG-3' ${ }^{\prime} / 5^{\prime}$-AAACTGACTACCTGATGCGT- $3^{\prime}$ ). The RNA was reverse transcribed for $1 \mathrm{~h}$ at $42{ }^{\circ} \mathrm{C}$. To inactivate the reverse transcriptase, samples were incubated at $95{ }^{\circ} \mathrm{C}$ for $5 \mathrm{~min}$. The amplification was accomplished by 40 cycles of denaturation for $30 \mathrm{~s}$ at $95{ }^{\circ} \mathrm{C}$, annealing for $30 \mathrm{~s}$ at the appropriate temperature for each primer pair, and extension for $30 \mathrm{~s}$ at $72{ }^{\circ} \mathrm{C}$. The RT-PCR was terminated by a final extension of $10 \mathrm{~min}$ at $72{ }^{\circ} \mathrm{C}$. The PCR products were analysed by agarose gel electrophoresis. $16 \mathrm{~S}$ rRNA was used as the internal control (using primers YEN16S-5'/YEN16S-3'). First, saturation curves with increasing amounts of total RNA were performed to determine the interval of linear increase in the relative amount of RT-PCR product and total RNA (data not shown).

Band-shift assays. Electrophoretic band-shift assays were performed as described previously (Madrid et al., 2002). A fragment corresponding to the promoter region of the $y m o A$ gene was amplified using primers pYmoA-F/pYmoA-R (5'-CTCTGTTTAGTAGTTACGGA-3'/5' -TTAAACGCATCAGGTAGTCA-3'). A PCR fragment corresponding to the upstream region of the hly operon of plasmid pHly152 amplified with primers CONT-1/CONT-2 (5'TTTACGCCCGTAAGGTGATG-3'/5' -TGAGTCACCTCTGACTGAGA$3^{\prime}$ ) was used as non-specific DNA.

\section{RESULTS}

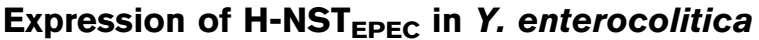 affects the growth rate and alters the protein expression pattern}

As a strategy to study the modulatory role of H-NS in Yersinia we decided, instead of isolating hns mutants, to interfere with H-NS's repressive ability. It has been previously shown in E. coli that some truncated forms of H-NS exhibit a dominant-negative phenotype (Williams et al., 1996). It has also been shown that some naturally

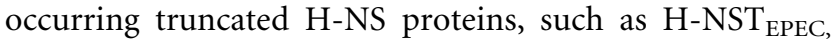
exhibit anti-HNS activity. The gene encoding $\mathrm{H}-\mathrm{NST}_{\mathrm{EPEC}}$ was first identified in a genomic island of an enteropathogenic E. coli strain (Williamson \& Free, 2005).

Considering that the amino acid sequences from the E. coli and $Y$. enterocolitica $\mathrm{H}-\mathrm{NS}$ proteins are very similar and, in addition, that $Y$. enterocolitica $\mathrm{H}-\mathrm{NS}$ protein can substitute for E. coli $\mathrm{H}-\mathrm{NS}$ function (Nieto et al., 2002), it should then be reasonable to expect that $\mathrm{H}-\mathrm{NST}_{\mathrm{EPEC}}$ protein would also interfere with $Y$. enterocolitica $\mathrm{H}-\mathrm{NS}$ function. We first tested that $\mathrm{H}-\mathrm{NST}_{\mathrm{EPEC}}$ does actually interact with $Y$. enterocolitica H-NS. Overexpressed $Y$. enterocolitica $\mathrm{H}-\mathrm{NSHis}$ was bound to a $\mathrm{Ni}^{2+}$-NTA agarose matrix and mixed with a cell extract containing overproduced $\mathrm{H}$ $\mathrm{NST}_{\text {EPEC. }}$ Imidazole-mediated elution of $\mathrm{H}-\mathrm{NSHis}_{6}$ protein resulted in co-elution of $\mathrm{H}_{-\mathrm{NST}_{\mathrm{EPEC}}}$ (Fig. 1). Next, Y. enterocolitica strain W22703 was transformed with plasmid pHSGHNSTE, which carries the $h n s T_{\mathrm{EPEC}}$ gene cloned in plasmid pHSG576. Plasmid pHSG576 was used as a control. Transformants were selected and their growth rate was compared to that of the parental strain. Transformants harbouring pHSGHNSTE showed a significantly reduced growth rate $\left(0.77 \pm 0.018 \mathrm{~h}^{-1}\right.$ at $37{ }^{\circ} \mathrm{C}$; $0.59 \pm 0.041 \mathrm{~h}^{-1}$ at $30{ }^{\circ} \mathrm{C}$ ) compared to those carrying plasmid pHSG576 $\left(0.94 \pm 0.007 \mathrm{~h}^{-1}\right.$ at $37^{\circ} \mathrm{C}$; $0.89 \pm 0.015 \mathrm{~h}^{-1}$ at $30{ }^{\circ} \mathrm{C}$ ) (Fig. 2). Expression in $Y$. enterocolitica of the $h n s T_{\mathrm{EPEC}}$ gene carried by plasmid pHSGHNSTE was confirmed by RT-PCR analysis using specific oligonucleotídes complementary to $h n s T_{\text {EPEC }}$ mRNA (data not shown). 
Table 2. Proteins showing altered expression levels in 2D-PAGE gels from strains W22703 and W22703(pHSGNSTE) that could be identified by MALDI-TOF MS/ESI-MS-MS

\begin{tabular}{|c|c|c|c|c|}
\hline Protein & $\begin{array}{l}\text { Identification } \\
\text { no. in Fig. } 3\end{array}$ & Gene & $\begin{array}{l}\text { Effect of } \mathrm{H}- \\
\text { NST }_{\text {EPEC }} \text { protein }\end{array}$ & Previous reported effects on expression \\
\hline Methylaspartate ammonia-lyase & 1 & YE4043 & Induction & \\
\hline Glycine betaine-binding periplasmic protein & 3 & proU & Induction & $\begin{array}{l}\text { Repression at } 37^{\circ} \mathrm{C} \text { in } Y \text {. pestis (Motin et al., 2004), } \\
\text { induction in E. coli and Salmonella hns mutants } \\
\text { (Hommais et al., 2001; Jordi \& Higgins, 2000) }\end{array}$ \\
\hline Hypothetical protein YE2691 & 5 & YE2691 & Induction & \\
\hline Hypothetical protein YE4025 & 6 & YE4025 & Induction & \\
\hline $\begin{array}{l}\text { GalU, UTP-glucose-1-phosphate } \\
\text { uridylyltransferase }\end{array}$ & 7 & galU & Induction & $\begin{array}{l}\text { Induction in a Salmonella hns mutant (Ono et al., } \\
\text { 2005) }\end{array}$ \\
\hline Hypothetical protein YE3397 & 10 & YE3397 & Repression & \\
\hline Rpe, ribulose-phosphate 3-epimerase & 11 & rpe & Repression & \\
\hline $\begin{array}{l}\text { FabA, 3-hydroxydecanoyl-(acyl carrier protein) } \\
\text { dehydratase }\end{array}$ & 12 & $f a b A$ & Repression & Repression at $37{ }^{\circ} \mathrm{C}$ in $Y$. pestis (Motin et al., 2004) \\
\hline TrpS, tryptophanyl-tRNA synthetase & 13 & $\operatorname{trpS}$ & Repression & \\
\hline $\begin{array}{l}\text { FabZ, } 3 R \text {-hydroxymyristoyl-(acyl carrier } \\
\text { protein) dehydratase }\end{array}$ & 14 & $f a b Z$ & Repression & Repression at $37^{\circ} \mathrm{C}$ in Y. pestis (Motin et al., 2004) \\
\hline Putative amino-acid-binding protein precursor & 15 & $g \ln H$ & Repression & Repression at $37{ }^{\circ} \mathrm{C}$ in $Y$. pestis (Motin et al., 2004) \\
\hline Hypothetical protein YE3403 & 16 & $y g g E$ & Repression & \\
\hline
\end{tabular}

We next analysed the protein expression pattern in strains W22703 and W22703(pHSGHNSTE). Total cell extracts were obtained and analysed by 2D-PAGE as described above. The results (Fig. 3) showed that, when compared to plasmid-free cells, cells harbouring plasmid pHSGHNSTE exhibit a detectable alteration of the protein expression pattern. Sixteen proteins corresponding to spots showing altered expression were excised and identified by MALDITOF/TOF MS or ESI-MS-MS (Table 2). The identified proteins participate in several physiological processes. One of them (ProV) corresponds to one of the best-studied examples of an H-NS-modulated protein in E. coli and other enteric bacteria (Jordi \& Higgins, 2000). W22703 cells harbouring plasmid pHSGHNSTE showed increased ProV expression, as has been shown in E. coli (Williamson \& Free, 2005). Two other proteins (UreG and GalU) have been reported to be modulated by $\mathrm{H}-\mathrm{NS}$ in Proteus mirabilis and Salmonella enterica serovar Typhimurium respectively (Ono et al., 2005; Poore \& Mobley, 2003). It is remarkable that several of the identified proteins (ProV, UreG, FabA, FabZ and $g \ln H$ gene product) show temperature-dependent expression in Yersinia pestis (Han et al., 2004; Motin et al., 2004). To correlate alterations in protein expression with transcription levels, we used RTPCR to measure transcription of some of the genes encoding proteins showing expression differences between strains W22703 and W22703(pHSGHNSTE). As expected,

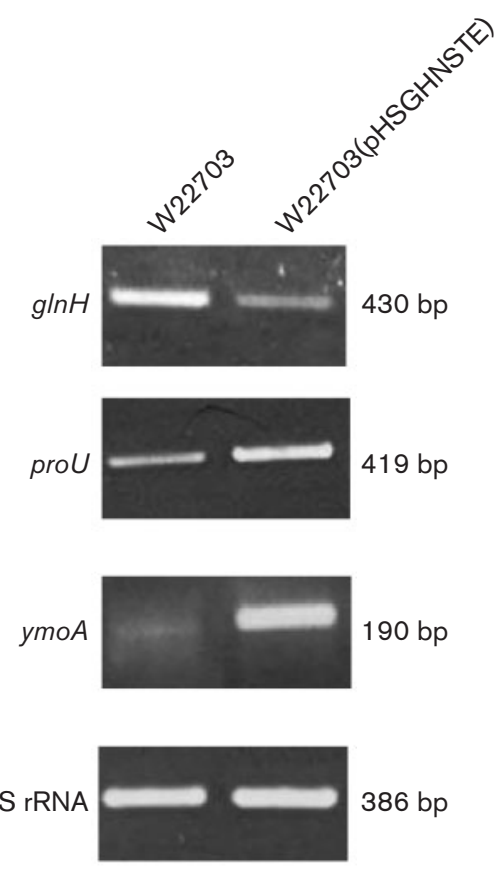

Fig. 4. RT-PCR analysis of transcription of the $g / n H$, proV and $y m o A$ genes from strains W22703 and W22703(pHSGHNSTE). $16 \mathrm{~S}$ rRNA was used as a control to confirm equivalent quantity of template loading. 

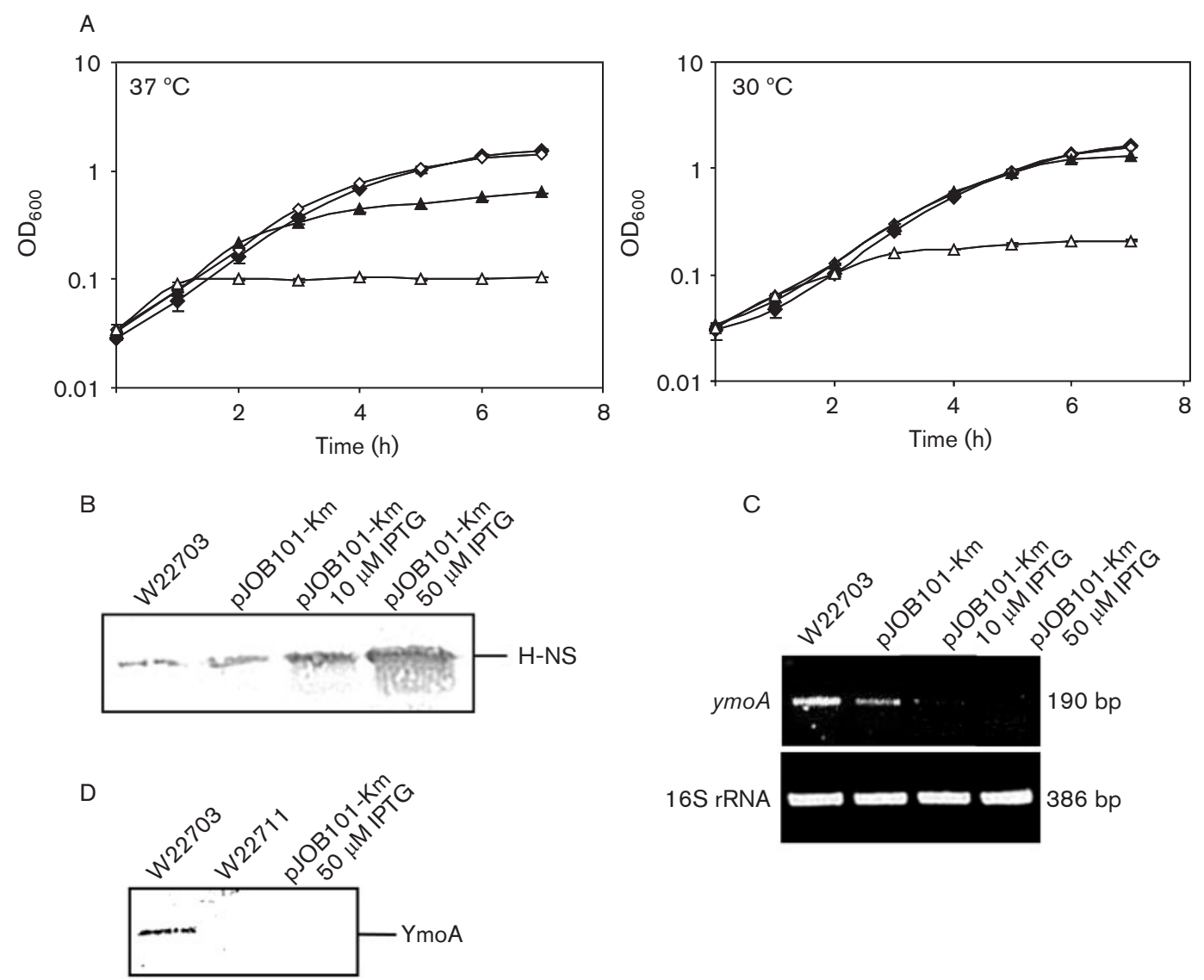

Fig. 5. Overexpression of the $h$ ns gene reduces the growth rate of strain $\mathrm{W} 22703$ and represses $y m o A$ transcription. (A) Growth of strains W22703 $(\diamond)$, W22703(pJOB101-Km) $(\diamond)$, W22703(pJOB101-Km) induced with $10 \mu \mathrm{M}$ IPTG $(\mathbf{\Delta})$ and W22703 (pJOB101-Km) induced with $50 \mu \mathrm{M} \mathrm{IPTG}(\triangle)$, in LB medium aerobically at $37{ }^{\circ} \mathrm{C}$ and $30{ }^{\circ} \mathrm{C}$. The mean $\pm \mathrm{SD}$ of three independent cultures for each strain is presented (error bars not shown where smaller than symbols). (B) Immunodetection of $\mathrm{H}-\mathrm{NS}$ protein in cell extracts. (C) RT-PCR analysis of $y m o A$ transcription in strains W22703, W22703(pJOB101-Km) and W22703(pJOB101-Km) induced with $10 \mu \mathrm{M}$ and $50 \mu \mathrm{M}$ IPTG at $30{ }^{\circ} \mathrm{C}$. 16S rRNA was used as a control to confirm equivalent quantity of template loading. (D) Immunodetection of YmoA protein in extracts from strains W22703, W22711 and W22703(pJOB101- Km) induced with $50 \mu \mathrm{M}$ IPTG and grown at $30{ }^{\circ} \mathrm{C}$.

the transcriptional data corroborated the protein expression data (Fig. 4).

\section{$\mathrm{H}-\mathrm{NS}$ represses transcription of the Y. enterocolitica ymoA gene}

The above results show that proteins exhibiting altered expression levels in cells expressing $\mathrm{H}-\mathrm{NST}_{\mathrm{EPEC}}$ are likely candidates to be regulated by H-NS in Y. enterocolitica. To further show that expression of H-NST $\mathrm{EPEC}_{\mathrm{EPC}}$ can be a useful approach to test H-NS-dependent gene expression in Yersinia, we decided to investigate whether H-NS modulates expression of the $y m o A$ gene. Whereas cross-regulation between H-NS-StpA and Hha-like proteins has been previously reported in E. coli (Hommais et al., 2001; Paytubi et al., 2004; Zhang et al., 1996), information about $\mathrm{H}-\mathrm{NS}$ modulating $y m o A$ expression in Yersinia was not available. We decided to measure $y m o A$ transcription both in cells expressing abnormally high $\mathrm{H}-\mathrm{NS}$ levels and in cells expressing $\mathrm{H}_{-} \mathrm{NST}_{\mathrm{EPEC}}$. RT-PCR experiments showed that, when compared to plasmid-free W22703 cells, cells harbouring plasmid pHSGHNSTE increased ymoA expression (Fig. 4). These results suggest that H-NS represses YmoA expression. This was confirmed by determining the effect of increased $\mathrm{H}$ NS levels on ymoA transcription. Plasmid pJOB101 contains the hns gene cloned under the control of the tac promoter. As strain W22703 is $A p^{r}$, we inserted a mini-Tn5 transposon in the $\mathrm{Ap}^{\mathrm{r}}$ determinant, generating plasmid $\mathrm{pJOB} 101-\mathrm{Km}$. W22703(pJOB101-Km) cells growing in the presence of IPTG overexpressed $\mathrm{H}-\mathrm{NS}$ and showed a reduced growth rate (Fig. 5A, B). ymoA transcription was measured in strains W22703 and W22703(pJOB101-Km) in the presence of different amounts of IPTG. H-NS overexpression resulted in $y m o A$ downregulation (Fig. 5C). Immunodetection of YmoA confirmed that cells overexpressing H-NS contain reduced levels of the YmoA protein (Fig. 5D). 


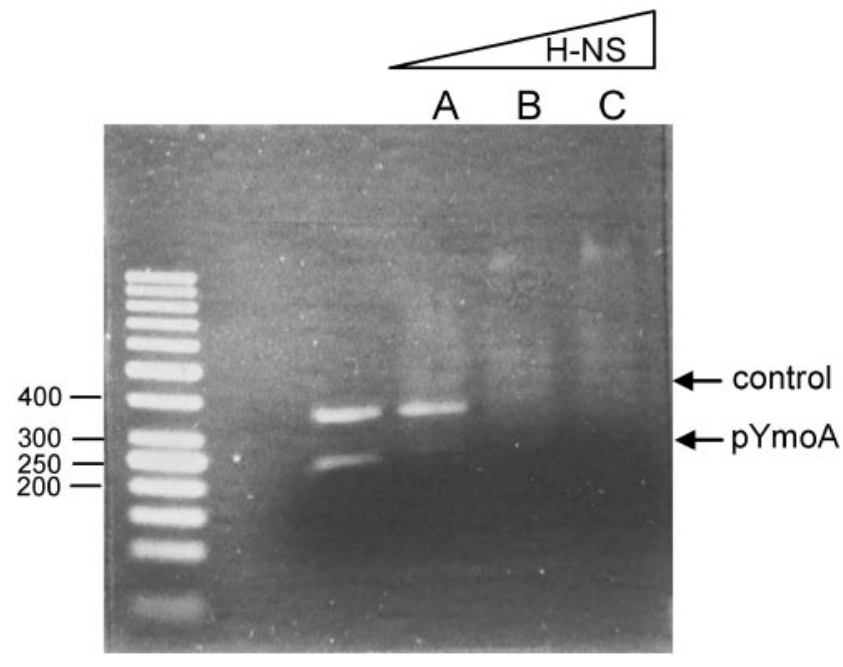

Fig. 6. Interaction of the $y m o A$ promoter region with $\mathrm{H}-\mathrm{NS}$. The DNA fragments used correspond to the $y m o A$ promoter ( $\mathrm{YYmoA}$ ) and a fragment from the hly operon (control) to which $\mathrm{H}-\mathrm{NS}$ does not show specific binding. No protein (lane A), 30 pmol (lane B) and $60 \mathrm{pmol}$ (lane $\mathrm{C}$ ) of purified $\mathrm{H}-\mathrm{NSH}$ is protein was added to the reactions.

\section{$\mathrm{H}-\mathrm{NS}$ binds to the $y m o A$ promoter region}

To confirm that H-NS is a repressor of the $y m o A$ gene, we tested $\mathrm{H}-\mathrm{NS}$ binding to the $y m o A$ promoter region. A competitive band-shift assay (Fig. 6) showed that H-NS exhibits preferential binding to the $y m o A$ promoter region, hence supporting the hypothesis that $\mathrm{H}-\mathrm{NS}$ modulates ymoA expression.

\section{DISCUSSION}

Several reports have shown that H-NS modulates expression of different genes from E. coli, Salmonella and Shigella (Dorman, 2004). In contrast, only few reports have shown a modulatory role for H-NS in Yersinia (Ellison \& Miller, 2006; Heroven et al., 2004; Pérez-Gutiérrez et al., 2007). The most likely reason is that the $h n s$ gene is essential in this genus. Hence, deregulated mutants obtained by random mutagenesis procedures are not going to map in the Yersinia hns gene. The previous finding that the YmoA protein is a relevant modulator in Yersinia (Cornelis et al., 1991; Ellison et al., 2003) and that this protein interacts with H-NS (Nieto et al., 2002) strongly suggested that $\mathrm{H}$ NS must also play an important modulatory role in this genus. All experimental approaches used by us (unpublished results) and others (Ellison \& Miller, 2006; Heroven et al., 2004) failed to isolate hns mutants in Yersinia. Therefore, alternative strategies that would allow study of the regulatory role of the H-NS protein in Yersinia should be developed. Rather than searching for the loss of H-NS function, we decided to partially interfere with $\mathrm{H}-\mathrm{NS}$ modulatory activity.
The results presented here strongly suggest that interference with H-NS function accounts for the altered expression levels of many proteins of strain W22703(pHSGHNSTE). Some of the identified proteins have already been reported to be modulated by H-NS in other enteric bacteria (ProV, UreG, GalU). A significant number have also been identified in $Y$. pestis as temperature-modulated (Han et al., 2004; Motin et al., 2004). Considering that H-NS is a well-characterized example of a temperature-dependent modulator (Ono et al., 2005) the above-referred results suggest that these proteins belong to the H-NS regulon.

Experiments showing that H-NS influences ymoA transcription further confirm that expression of $\mathrm{H}_{-\mathrm{NST}} \mathrm{EPEC}_{\mathrm{E}}$ protein represents a valuable strategy to test H-NSdependent modulation of Yersinia genes. H-NS overexpression resulted in $y m o A$ downregulation, and H-NST ${ }_{\text {EPEC }}$ interference with $\mathrm{H}-\mathrm{NS}$ activity resulted in $y m o A$ upregulation. The observation that H-NS levels modulate ymoA expression in Yersinia matches results reported in E. coli for the hns and hha genes: hha expression increases in hns mutants (Hommais et al., 2001).

A still unanswered question is the reason why the hns gene is essential in Yersinia. The fact that (i) E. coli hns mutants are viable and (ii) the E. coli paralogue StpA is overexpressed in hns mutants (Sondén \& Uhlin, 1996) would suggest that the lack of an H-NS paralogue accounts for the lethality of the hns allele in Yersinia. However, the fact that E. coli double hns stpA mutants are viable argues against this. When considering the recent view that H-NS silences large AT-rich stretches of laterally acquired DNA (Dorman, 2007; Lucchini et al., 2006; Navarre et al., 2006; Pflum, 2006), it could be suggested that deregulated expression of genes located within these genomic islands can be lethal in Yersinia. Nevertheless, hns mutants cannot be isolated in strains lacking some of these sequences (e.g. the pYV plasmid). As an alternative hypothesis, we propose the following. Temperature transition in Yersinia results in drastic alterations in the protein expression pattern and cell physiology (Han et al., 2004; Motin et al., 2004). Both the fact that $\mathrm{H}-\mathrm{NS}$ interacts with YmoA and results presented in this work suggest a role for H-NS in modulating proteins from the temperature regulon. H-NS loss would then result in major global physiological alterations rendering cells unable to grow in conventional culture media.

\section{ACKNOWLEDGEMENTS}

This work was supported by grant no. BIO2004-02747 from the Ministry of Science and Technology of Spain and by grant 2005SGR00635 from the Generalitat of Catalonia. J.I.P. was the recipient of a Research and Teaching grant from the University of Barcelona. Trypsinization and analysis by MALDI-TOF MS and ESIMS-MS were done at 'Unitat de Proteòmica dels Serveis CientíficoTècnics de la Universitat de Barcelona'. We thank Professor Guy 
Cornelis for kindly providing us with $Y$. enterocolitica strains, Professor A. Free for plasmid pHSGHNSTE, the National BioResource Project (NIG, Japan): E. coli for plasmid pHSG576, and Professor V. de Lorenzo for providing us with different genetic tools. X. Cañas (University of Barcelona) helped us to obtain the anti$\mathrm{H}-\mathrm{NS}$ antibodies. C. Balsalobre is acknowledged for critical reading of the manuscript.

\section{REFERENCES}

Balsalobre, C., Juárez, A., Madrid, C., Mouriño, M., Prenafeta, A. \& Muñoa, F. J. (1996). Complementation of the hha mutation in Escherichia coli by the $y m o A$ gene from Yersinia enterocolitica: dependence on the gene dosage. Microbiology 142, 1841-1846.

Conchas, R. F. \& Carniel, E. (1990). A highly efficient electroporation system for transformation of Yersinia. Gene 87, 133-137.

Cornelis, G. R. \& Colson, C. (1975). Restriction of DNA in Yersinia enterocolitica detected by recipient ability for a derepressed $\mathrm{R}$ factor from Escherichia coli. J Gen Microbiol 87, 285-291.

Cornelis, G. R., Sluiters, C., Delor, I., Gelb, D., Kaninga, K., Lambert de Rouvroit, C., Sory, M. P., Vanooteghem, J. C. \& Michaelis, T. (1991). ymoA, a Yersinia enterocolitica chromosomal gene modulating the expression of virulence functions. Mol Microbiol 5, 1023-1034.

De Lorenzo, V., Herrero, M., Jakubzik, U. \& Timmis, K. N. (1990). Mini-Tn 5 transposon derivatives for insertion mutagenesis, promoter probing, and chromosomal insertion of cloned DNA in Gramnegative eubacteria. J Bacteriol 172, 6568-6572.

Dorman, C. J. (2004). H-NS: a universal regulator for a dynamic genome. Nat Rev Microbiol 2, 391-400.

Dorman, C. J. (2007). H-NS, the genome sentinel. Nat Rev Microbiol 5, 157-161.

Dorman, C. J. \& Deighan, P. (2003). Regulation of gene expression by histone-like proteins in bacteria. Curr Opin Genet Dev 13, 179-184.

Ellison, D. W. \& Miller, V. L. (2006). H-NS represses inv transcription in Yersinia enterocolitica through competition with RovA and interaction with YmoA. J Bacteriol 188, 5101-5112.

Ellison, D. W., Young, B., Nelson, K. \& Miller, V. L. (2003). YmoA negatively regulates expression of invasin from Yersinia enterocolitica. J Bacteriol 185, 7153-7159.

Falconi, M., Colonna, B., Prosseda, G., Micheli, G. \& Gualerzi, C. O. (1998). Thermoregulation of Shigella and Escherichia coli EIEC pathogenicity. A temperature-dependent structural transition of DNA modulates accessibility of VirF promoter to transcriptional repressor H-NS. EMBO J 17, 7033-7043.

Han, Y., Zhou, D., Pang, X., Song, Y., Zhang, L., Bao, J., Tong, Z., Wang, J., Guo, Z. \& other authors (2004). Microarray analysis of temperature-induced transcriptome of Yersinia pestis. Microbiol Immunol 48, 791-805.

Heroven, A. K., Nagel, G., Tran, H. J., Parr, S. \& Dersch, P. (2004). RovA is autoregulated and antagonizes H-NS-mediated silencing of invasion and rovA expression in Yersinia pseudotuberculosis. Mol Microbiol 53, 871-888.

Herrero, M., De Lorenzo, V. \& Timmis, K. N. (1990). Transposon vectors containing non-antibiotic resistance selection markers for cloning and stable chromosomal insertion of foreign genes in gramnegative bacteria. J Bacteriol 172, 6557-6567.

Hoffmann, A. \& Roeder, R. G. (1991). Purification of His-tagged proteins in non-denaturing conditions suggests a convenient method for protein interaction studies. Nucleic Acids Res 19, 6337-6338.

Hommais, F., Krin, E., Laurent-Winter, C., Soutourina, O., Malpertuy, A., Le Caer, J. P., Danchin, A. \& Bertin, P. (2001). Large-scale monitoring of pleiotropic regulation of gene expression by the prokaryotic nucleoidassociated protein, H-NS. Mol Microbiol 40, 20-36.

Johansson, J., Eriksson, S., Sondén, B., Wai, S. N. \& Uhlin, B. E. (2001). Heteromeric interactions among nucleoid-associated bacterial proteins: localization of StpA-stabilizing regions in $\mathrm{H}-\mathrm{NS}$ of Escherichia coli. J Bacteriol 183, 2343-2347.

Jordi, B. J. \& Higgins, C. F. (2000). The downstream regulatory element of the proU operon of Salmonella typhimurium inhibits open complex formation by RNA polymerase at a distance. J Biol Chem 275, 12123-12128.

Juárez, A., Hughes, C., Vogel, M. \& Goebel, W. (1984). Expression and regulation of the plasmid-encoded haemolysin determinant of Escherichia coli. Mol Gen Genet 197, 196-203.

Lucchini, S., Rowley, G., Goldberg, M. D., Hurd, D., Harrison, M. \& Hinton, J. C. (2006). H-NS mediates the silencing of laterally acquired genes in bacteria. PLoS Pathog 2, e81.

Madrid, C., Nieto, J. M., Paytubi, S., Falconi, M., Gualerzi, C. \& Juárez, A. (2002). Temperature- and H-NS-dependent regulation of a plasmidencoded virulence operon expressing Escherichia coli hemolysin. J Bacteriol 184, 5058-5066.

Madrid, C., Balsalobre, C., García, J. \& Juárez, A. (2007a). The novel Hha/YmoA family of nucleoid-associated proteins: use of structural mimicry to modulate the activity of the H-NS family of proteins. Mol Microbiol 63, 7-14.

Madrid, C., García, J., Pons, M. \& Juárez, A. (2007b). Molecular evolution of the H-NS protein: interaction with Hha-like proteins is restricted to Enterobacteriaceae. J Bacteriol 189, 265-268.

Mikulskis, A. V. \& Cornelis, G. R. (1994). A new class of proteins regulating gene expression in enterobacteria. Mol Microbiol 11, 77-86.

Miller, V. L. \& Mekalanos, J. J. (1988). A novel suicide vector and its use in construction of insertion mutations: osmoregulation of outer membrane proteins and virulence determinants in Vibrio cholerae requires toxR. J Bacteriol 170, 2575-2583.

Motin, V. L., Georgescu, A. M., Fitch, J. P., Gu, P. P., Nelson, D. O., Mabery, S. L., Garnham, J. B., Sokhansanj, B. A., Ott, L. L. \& other authors (2004). Temporal global changes in gene expression during temperature transition in Yersinia pestis. J Bacteriol 186, 6298-6305.

Navarre, W. W., Porwollik, S., Wang, Y., McClelland, M., Rosen, H., Libby, S. J. \& Fang, F. C. (2006). Selective silencing of foreign DNA with low GC content by the H-NS protein in Salmonella. Science 313, 236-238.

Nieto, J. M., Madrid, C., Prenafeta, A., Miquelay, E., Balsalobre, C., Carrascal, M. \& Juárez, A. (2000). Expression of the hemolysin operon in Escherichia coli is modulated by a nucleoid-protein complex that includes proteins Hha and H-NS. Mol Gen Genet 263, 349-358.

Nieto, J. M., Madrid, C., Miquelay, E., Parra, J. L., Rodríguez, S. \& Juárez, A. (2002). Evidence for direct protein-protein interaction between members of the enterobacterial Hha/YmoA and H-NS families of proteins. J Bacteriol 184, 629-635.

Noegel, A., Rdest, U. \& Goebel, W. (1981). Determination of the functions of hemolytic plasmid pHly152 of Escherichia coli. J Bacteriol 145, 233-247.

Ono, S., Goldberg, M. D., Olsson, T., Esposito, D., Hinton, J. C. \& Ladbury, J. E. (2005). H-NS is a part of a thermally controlled mechanism for bacterial gene regulation. Biochem J 391, 203-213.

Paytubi, S., Madrid, C., Forns, N., Nieto, J. M., Balsalobre, C., Uhlin, B. E. \& Juárez, A. (2004). YdgT, the Hha paralogue in Escherichia coli, forms heteromeric complexes with H-NS and StpA. Mol Microbiol 54, 251-263.

Pérez-Gutiérrez, C., Llompart, C. M., Skurnik, M. \& Bengoechea, J. A. (2007). Expression of the Yersinia enterocolitica pYV-encoded type III 
secretion system is modulated by lipopolysaccharide $\mathrm{O}$-antigen status. Infect Immun 75, 1512-1516.

Pflum, M. K. (2006). H-NS gives invading DNA the silent treatment. Nat Chem Biol 2, 400-401.

Poore, C. A. \& Mobley, H. L. (2003). Differential regulation of the Proteus mirabilis urease gene cluster by UreR and H-NS. Microbiology 149, 3383-3394.

Rimsky, S. (2004). Structure of the histone-like protein H-NS and its role in regulation and genome superstructure. Curr Opin Microbiol 7, 109-114.

Rohde, J. R., Fox, J. M. \& Minnich, S. A. (1994). Thermoregulation in Yersinia enterocolitica is coincident with changes in DNA supercoiling. Mol Microbiol 12, 187-199.

Simon, R., Priefer, U. \& Pühler, A. (1983). A broad host range mobilization system for in vivo genetic engineering: transposon mutagenesis in gram negative bacteria. Bio/Technology 1, 784-791.

Sondén, B. \& Uhlin, B. E. (1996). Coordinated and differential expression of histone-like proteins in Escherichia coli: regulation and function of the H-NS analog StpA. EMBO J 15, 4970-4980.

Stella, S., Falconi, M., Lammi, M., Gualerzi, C. O. \& Pon, C. L. (2006). Environmental control of the in vivo oligomerization of nucleoid protein H-NS. J Mol Biol 355, 169-174.
Straley, S. C. \& Perry, R. D. (1995). Environmental modulation of gene expression and pathogenesis in Yersinia. Trends Microbiol 3, 310-317.

Studier, F. W., Rosenberg, A. H., Dunn, J. J. \& Dubendorff, J. W. (1990). Use of T7 RNA polymerase to direct expression of cloned genes. Methods Enzymol 185, 60-89.

Tupper, A. E., Owen-Hughes, T. A., Ussery, D. W., Santos, D. S., Ferguson, D. J. P., Sidebotham, J. M., Hinton, J. D. C. \& Higgins, C. F. (1994). The chromatin-associated protein H-NS alters DNA topology in vitro. $E M B O J 13,258-268$.

Williams, R. M., Rimsky, S. \& Buc, H. (1996). Probing the structure, function, and interactions of the Escherichia coli H-NS and StpA proteins by using dominant negative derivatives. J Bacteriol 178, 4335-4343.

Williamson, H. S. \& Free, A. (2005). A truncated H-NS-like protein from enteropathogenic Escherichia coli acts as an H-NS antagonist. Mol Microbiol 55, 808-827.

Zhang, A., Rimsky, S., Reaban, M. E., Buc, H. \& Belfort, M. (1996). Escherichia coli protein analogs StpA and H-NS: regulatory loops, similar and disparate effects on nucleic acid dynamics. EMBO J 15, 1340-1349.

Edited by: J.-H. Roe 